\section{Equipment up for grabs} US universities share others' troubles over equipment, but have more options to play with.

THE US research universities have been complaining with increasing conviction, over the past few years, about the need for modern equipment. Last week, the Committee on Science and Technology of the House of Representatives, apparently sympathetic to the complaints, was presented with the result of a three-year study of the problem by a task force of the Association of American Universities (AAU) under Richard A. Zdanis, vice-provost of Johns Hopkins University. The Zdanis committee's case is necessarily somewhat general, based more on trends discernible in federal budgets and the like than on the more compelling anecdotal evidence showing how particular research programmes of acknowledged worth are being hampered. To make up for this, the report is filled with a string of eminently sensible suggestions.

Before too many tears are shed, it should be recognized that what has happened in the United States is not very different from what has happened elsewhere, in Western Europe in particular. (Japan is a different case). Although the US government's spending on basic research continues to grow, the pace of growth is smaller now than in the happy 1960 s, with the result that prudent administrators, in the universities and at the grantmaking agencies, prefer to spend money on people rather than on research equipment. But during the same period, the design of standard equipment has been improved, making equipment more productive of material or data (which is its purpose, after all) but also more costly. Similarly, entirely novel kinds of research equipment have made their appearance, making possible tasks that could not previously have been tackled in university laboratories. The number of places now equipped with analytical equipment controlled by microprocessors, and even with the machines for making semiconductor chips for microprocessors, is a sufficient proof of that. That is the essence of the problem described last week. What can be done about it?

Mercifully, for US universities, the importance of the problem seems already to have been seized by the agencies. While the provision of research equipment through the regular research-grant mechanisms has by no means shrunk to nothing, the National Science Foundation, the Department of Defense (DoD) and the Department of Energy between them have recently committed very substantial sums to make good what seems to be a growing shortage. The AAU study itself is a manifestation of this awareness (and has indeed been supported by a grant from the National Science Foundation). Inevitably, the committee pleads for more of the same, together with the removal of some of the present impediments to easy dealing between the agencies and the universities - the requirement (under DoD grants and contracts) that there should be a search in the Pentagon's storehouse of discarded equipment before an equivalent piece of hardware can be provided at government cost is a worthy casualty. What the AAU committee seems not to have appreciated is the danger that the present alarm about the deficiencies of equipment will become institutionalized, and separate from other kinds of research support, with the consequence that there will be the eyes of two needles through which each research project must pass. There is also among the committee's proposals a trusting faith in the innocence of the Office of Management and Budget, which will presumably have an opinion on the suggestion that universities that have acquired equipment out of their own funds or otherwise should be allowed to charge annual depreciation against research grants when these materialize.

This is the bread and butter of the AAU report, to which it must be hoped that the Congress will respond. The frosting on the cake, the required reading for provosts from now on, is the section on self-help. Inevitably, universities are enjoined to be self-conscious about the uncovenanted costs of expensive equipment (such as start-up and maintenance), not to mention the need to keep advanced equipment performing efficiently by means of a sufficient force of technical help. It is no surprise that individual universities have been deterred from entering costly fields of research, which may not be bad as it seems. Does the interest of the United States require that each of more than fifty research universities should be able to make a start on molecular beam epitaxy at a cost of $\$ 1$ million each? (And who was the chemistry professor whose installation at an eastern seaboard university cost $\$ 2$ million, expensive even now?) More down to earth, the committee had some useful suggestions as to how people may be able to buy expensive equipment by running two consecutive grants together, or even by leasing equipment.

More adventurous university administrators will be even more enthused by the recommendations in the AAU report that universities should more deliberately explore the use of debt financing for the purchase of equipment. (The committee responsible notes with some surprise that it knows of no university computer centre financed by such means.) Here the trick is to use the status of universities as tax-exempt institutions to raise money at low rates of interest, recovering the cost of grants not yet awarded; the AAU committee is right to commend such schemes while warning of the risks (chiefly, that expected grants do not materialize). But it may matter more than the committee allows that researchers do not like this way of acquiring equipment. For the short term, there is probably more to be said for making sure that university administrators understand the tax benefits of equipment grants and gifts by private donors. (AAU provides worked examples.) And in the language of resource economics, it is sad that there are still so few institutions that have followed the University of Iowa in setting up (and keeping going) internal arrangements for sharing not merely equipment but the problems that go with its ownership.

\section{Protection from whom?}

Somebody should take a serious look at space launching costs.

THE US government has returned from the summer holidays in a sombre frame of mind on external trade policy. The Congress has been conscious for several months of the pressure from its constituents to keep foreign imports out of the United States. Now the administration is making conciliatory noises, offering still vague external negotiations with exporters to the United States. President Reagan's calculation is no doubt that it would be better to make small concessions now than to veto whatever comes up from Congress only to find the veto overridden. What everybody overlooks is the certainty that general protection beneath the shadow of the US federal deficit will have disastrous consequences for world trade.

But is it not unfair that people in the United States should be out of work (although the numbers are dramatically reduced this month) because people elsewhere will work for lower wages, or because their governments subsidize the products that they make? Before the Congress takes this argument too seriously, it should listen carefully to what the head of Arianespace was saying last week about the effects of US export subsidies on the space launcher business. The issue has been well rehearsed in the report from the Office of Technology Assessment on space competition, published earlier this year. The present basis for charging for the use of the US shuttle is that even if the cargo bay were unfilled, the shuttle would still fly. The present cost of a full bay is $\$ 80$ million, but it is intended that the cost should rise by 1988 to an amount estimated at $\$ 125$ million (in 1984 money). M. d'Allest's complaint is that the shuttle's present costs are less than they should be, although he is also open to the complaint that Arianespace can offer customers more attractive financing terms than NASA is allowed to offer. At best, the kettle is abusing the pot. At worst, the US shuttle is being as heavily subsidized in its competition with the European rocket as are the whole of the products of the textile industries now threatened from the United States. 